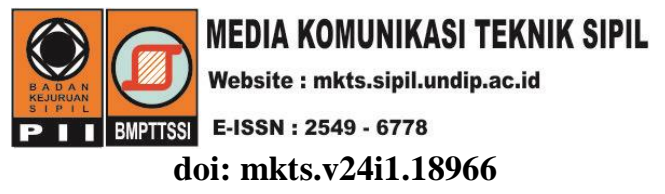

\title{
Indeks Stakeholders Pengelolaan Daerah Aliran Sungai dengan Pendekatan KISS di Indonesia
}

\author{
Ignatius Sriyana \\ Departemen Teknik Sipil, Fakultas Teknik, Universitas Diponegoro, Semarang \\ sriyana@live.undip.ac.id
}

Received: 16 Mei 2018 Revised: 19 Juli 2018 Accepted: 24 Juli 2018

\begin{abstract}
Integrated watershed management (IWM) using KISS (coordination, integration, synchronisation, and synergy) method is believed to be the answer for problems lingering the integrated watershed management in Indonesia. How successful the management is depends on how capable of stakeholders are to performing coordination, integration, synchronisation, and synergy in managing the watershed. This study aimed at measuring the rates of coordination, integration, synchronisation, and synergy performed by each stakeholder by applying an "Index Rate" instrument. Research findings revealed that, simultaneously, the coordination, integration, synchronisation, and synergy obtained by the watershed management stakeholders resulted in a moderate rate (71.4). Partially, the rates obtained were as follows: moderate coordination (72.69); moderate integrity (72.50); moderate synchronisation (70.34); and moderate synergy (70.05).
\end{abstract}

Keywords: Indexs, stakeholders, watershed, KISS

\begin{abstract}
Abstrak
Pengelolaan daerah aliran sungai terpadu (PDAST) dengan metode KISS (koordinasi, integrasi, sinkronisasi dan sinergitas) dipandang sebagai jawaban atas problematika dalam pengelolaan DAS terpadu di Indonesia. Seberapa besar keberhasilan pengelolaan DAS terpadu tersebut ditentukan oleh seberapa besar para stakeholder telah melakukan koordinasi, integrasi, sinkronisasi dan sinergitas dalam melakukan pengelolaan DAS. Penelitian ini bertujuan mengukur seberapa besar tingkat koordinasi, integrasi, sinkronisasi dan sinergitas telah dilakukan oleh masing-masing stakeholder dengan menggunakan instrument "Angka Indeks". Hasil penelitian menunjukkan bahwa secara umum tingkat koordinasi, integrasi, sinkronisasi dan sinergitas yang telah dilakukan oleh stakeholder DAS termasuk dalam kriteria sedang dengan angka indeks 71,4. Secara parsial tingkat koordinasi memiliki kriteria sedang dengan indeks 72,69; timgkat integritas memiliki kreteria sedang dengan indeks 72,50; tingkat sinkronisasi memiliki kreteria sedang dengan indeks 70,34 dan tingkat sinergitas memiliki kriteria sedang dengan indeks 70,05.
\end{abstract}

Kata kunci: Indeks, stakeholders, DAS, KISS

\section{Pendahuluan}

Terjadinya penurunan kualitas lingkungan pada daerah aliran sungai (DAS) di Indonesia disebabkan adanya pengelolaan sumber daya alam yang tidak ramah lingkungan dan meningkatnya potensi ego sektoral dan ego kewilayahan karena pemanfaatan dan penggunaan sumber daya alam pada DAS tersebut (Peraturan Pemerintah Nomor 37, 2012), terkadang terjadi konflik kepentingan. Degradasi lingkungan pada DAS tersebut menunjukkan bahwa kesehatan DAS mengalami penurunan, hal tersebut dapat terindentifikasi dimana kalau musim hujan terjadi banjir, musim kemarau mengalami kekurangan, erosi sedimentasi dan terjadi penurunan kualitas air (Erdogan, 2013). Menurut Jones, et al (2002) kesehatan DAS dipakai sebagai ukuran seberapa baik kegiatan dalam pengelolaan sumber daya, yang mampu menyeimbangkan kebutuhan antropogenik dan fungsi ekologi dan integritas di dalam DAS. Untuk mewujudkan perubahan akibat terdegradasinya lingkungan pada DAS yang ada perlu pendekatan pengelolaan DAS terpadu yang melibatkan 
stakeholders (Mutekanga, et al., 2013; Winnegge, 2005; Bewket, 2003).

Stakeholders (pemangku kepentingan) didefinisikan sebagai kelompok atau individu yang dapat mempengaruhi atau dipengaruhi oleh pencapaian tujuan korporasi, dimana jika sekelompok individu dapat mempengaruhi perusahaan atau dipengaruhi olehnya, dan membalas maka manajer harus khawatir terhadap kelompok individu tersebut, perlu langkah strategi eksplisit yang dilakukan oleh manager untuk menangani stakeholders tersebut (Freeman, 1984). Tetapi lebih jauh pemikiran (Freeman, 2004), perlunya strategi hubungan stakeholders, sangat membantu untuk menangani jenis perubahan itu menghadapi perusahaan mereka, daripada tugas (merumuskan, menerapkan, mengevaluasi). Stakeholders yang terlibat dalam pengelolaan DAS di Indonesia meliputi beberapa instansi diantaranya pemerintah pusat, pemerintah daerah, perguruan tinggi, asosiasi profesi, anggota legestatif, kuminitas peduli sungai, lembaga swadaya masyarakat, komunitas peduli DAS, BUMN, masyarakat. Semua harus disusun, diatur secara strategis (Freeman \& McVea, 2001), supaya dengan partisipasi atau keterlibatan semua stakeholders tersebut maka hasil penyelesaian akan dicapai (Grigg, 1998) sesuai harapan. Menurut Donaldson \& Preston (1995) mendefinisikan gagasan stakeholders perusahaan, teori ini telah berhasil menjadi deskriptif, instrumental dan normative, dimana kinerja organisasi harus diperiksa apakah stakeholders berkinerja baik atau tidak. Hal serupa dalam penyenggaraan pengelolaan DAS di Indonesia. Pendekatan ini melihat perusahaan sebagai kumpulan berupa hubungan antara berbagai kegiatan antar stakeholders, maka seorang manajer harus berupaya dengan menggabungkan satu dengan lainnya, sehingga membuat mereka saling berinteraksi dalam proses penciptaan nilai (Sciarelli \& Tani, 2013), bila mengalami konflik antara stakeholders maka perlu penyelesaian dengan pendekatan diadakan pertemuan, negosiasi, dialog antar Stakeholders, menuju kesepakatan bersama dengan transparansi dan keadilan, saling berbagi pengetahuan tentang perencanaan, termasuk mengembangkan jejaring, sehingga dapat meningkatkan kerjasama dalam penggunaan sumber daya pada DAS (Chanya et al., 2013). Permasalahan saat ini dalam penyelenggaraan RPDAST, melalui program (Borisova et al., 2012) perencanaan, pelaksanaan, peran serta dan pemberdayaan masyarakat, pendanaan, monitoring dan evaluasi, pembinaan dan pengawasan yang telah dilaksanakan oleh stakeholders belum diketahui dengan pasti. Dengan permasalahan tersebut, maka sejauh mana realisasi penyelenggaraan pengelolaan DAS yang telah dilaksanakan oleh stakeholders, supaya dapat diketahui program mana yang kurang dan perlu ditingkatkan.

Tujuan penelitian ini adalah mengukur seberapa besar tingkat KISS (koordinasi, integrasi, sinkronisasi dan sinergitas), yang telah dilakukan oleh masing-masing stakeholders dalam pengelolaan DAS dengan menggunakan instrumen angka indeks.

\section{Variabel, populasi dan sampel}

Variabel yang diukur dalam penelitian ini ada 4(empat) variabel yaitu: koordinasi, integrasi, sinkronisasi dan sinergitas. Semua variabel penelitian diukur secara ordinal dengan skala likert melalui indikator-indikator yang membangunnya. Indikator variabel koordinasi meliputi: keterlibatkan stakeholders, frekwensi pertemuan antar stakeholders, keterlibatan masyarakat, koordinasi dalam perencanaan, koordinasi dalam pelaksanaan kegiatan, dan koordinasi dalam program monitoring dan evaluasi. Indikator variabel integrasi meliputi: integrasi dalam perencanaan, adanya kesepakatan wilayah kerja, adanya kesepakatan wilayah substansi kerja, pembagian beban biaya dan manfaat antar stakeholders, integrasi dalam program monitoring dan evaluasi. Indikator variabel sinkronisasi meliputi: sinkronisasi data, sinkronisasi program kerja, sinkronisasi waktu pelaksanaan program kegiatan, adanya tujuan secara parsial yang proporsional, adanya tujuan lintas sektoral, kesesuaian program monitoring dan evaluasi. Indikator variabel sinergitas meliputi: adanya kesepakatan perencanaan program, pelaksanaan kegiatan dengan pendekatan adaptif terhadap perubahan kondisi yang dinamis dan sesuai dengan karakteristik wilayah DAS, keterlibatan masyarakat dalam kegiatan di wilayah hulu, tengah dan hilir, pelaksanaan kegiatan mencerminan kerja sama yang saling melengkapi.

Populasi dalam penelitian ini adalah seluruh stakeholders DAS di Indonesia, dan sebagai sampelnya adalah peserta Focus Group Discussion (FGD) Hari Air Dunia XV111, "Kemitraan dalam upaya pelestarian dan perlindungan sumber daya air" oleh Kementerian Pekerjaan Umum dan Perumahan Rakyat \& Kementerian Lingkungan Hidup dan Kehutanan Republik Indonesia, pada tanggal 6 april 2018, bertempat di Universitas Diponegoro Semarang, yang terdiri dari 65 perwakilan wilayah DAS dari seluruh Indonesia. Metode pengumpulan data dilakukan dengan cara angket, yaitu dengan membagikan kuesioner disertai lembar wawancara. 


\section{Metode Analisis}

Analisis dalam penelitian ini dibagi menjadi dua tahapan, yaitu analisis uji kualitas data yang meliputi uji validitas dan reliabilitas dan analis diskriptif dengan menggunakan metoda angka indeks

\section{Uji validitas dan reliabilitas}

Setelah diperoleh data yang pengukurannya menggunakan kuesioner selanjutnya dilakukan uji validitas dan reliabilitas terhadap data yang diperoleh tersebut, bila diperoleh hasil yang tidak valid maka data-data yang yang diperoleh dengan item tersebut tidak digunakan. Validitas menunjukan sejauh mana kesesuaian kuesioner/instrumen ukur dengan data yang diukur. Validitas diperoleh melalui teknik korelasi product moment pearson, sedangkan reliabilitas alat ukur diketahui melalui koefisien Alpha Cronbach. Kedua analisis tersebut dihitung dengan menggunakan program komputer Statistical Packages for Social Science (SPSS) versi 20.00 (Ghozali, 2011) validitas dan reliabilitas.

\section{Kriteria validitas}

Corrected item - total corelation $(r$ test $)>r$ kritical ( $r$ table), maka item pernyataan adalah valid sehingga akan menghasilkan data yang valid, dan sebaliknya, corrected item - total corelation $(r$ test $)<r$ kritical ( $r$ table) maka item pernyataan adalah tidak valid sehingga akan menghasilkan data yang tidak valid juga.

\section{Kriteria reliabilitas}

Koefisien Cronbach's Alpha > 0,6 maka variabel yang diukur dengan item-item pernyataan tersebut adalah reliabel, dan sebaliknya. Koefisien Cronbach's Alpha <0,6 maka variabel yang diukur dengan item-item pernyataan tersebut adalah tidak reliabel.

\section{Analisis indeks}

Analisis ini untuk mengukur seberapa besar tingkat KISS, yang telah dilakukan oleh masing-masing stakeholders dalam pengelolaan DAS. Tahapan dalam perhitungan indeks meliputi: menentukan angka indeks, menentukan katagori, membuat simpulan. Penentuan angka indeks dengan menggunakan Persamaan 1 dan Persamaan 2 (Ferdinand, 2006 ).

$\mathrm{I}=(\Sigma \mathrm{Fi} \cdot \mathrm{Xi}): \mathrm{n}$

dimana I adalah indeks, $F i$ adalah prosentase jumlah responden yang memberikan jawaban atas statemen kuesioner ke I, $X i$ adalah score jawaban atas statemen kuesioner ke i dan $\mathrm{n}$ adalah jumlah item jawaban.

Teknik score dan skala linkert (dimodifikasi) jawaban atas pertanyaan dibentang dari STS (sangat tidak setuju) score: 1 , TS (tidak setuju) score: 2, S (setuju) score: 3 , SS (sangat setuju) score: 4.

Penentuan interval katagori (p):

$\mathrm{p}=(\mathrm{DTT}-\mathrm{DTR}) / \mathrm{k}$

dimana $\mathrm{p}$ merupakan panjang interval katagori; DTT merupakan data tertinggi, yaitu nilai angka indeks dimana seluruh responden menjawab. DTR merupakan data terendah, yaitu nilai angka indeks dimana seluruh responden menjawab STS, dan $\mathrm{k}$ adalah jumlah kategori yang ditentukan oleh peneliti secara arbiter.

Kategori yang diperoleh sebagai berikut: dengan menggunakan data terendah, data tertinggi dan interval katagori maka dapat disusun tabel kategori pada Tabel 1.

Tabel 1. Batasan indeks kategori

\begin{tabular}{ccc}
\hline No & Indeks & Kategori $*$ \\
\hline 1 & $25,00--<50,00$ & kurang \\
2 & $50,00--<75,00$ & sedang \\
3 & $75,00--100,00$ & bagus \\
\hline
\end{tabular}

\section{Hasil}

\section{Uji validitas dan reliabilitas}

1. Uji validitas variabel "koordinasi"

Dari hasil analisis validitas dengan menggunakan program SPSS diperoleh hasil (Tabel 2).

Nilai corekted item - total correlation untuk semua indikator lebih besar dari 0,23 yang artinya seluruh indikator yang membangun variabel "koordinasi" adalah valid atau sesuai antara instrument dengan yang diukurnya.

2. Uji reliabilitas variabel "koordinasi"

Analisis reliabilitas variabel koordinasi dengan menggunakan program SPSS diperoleh hasil Cronbach's Alpha $=0,863$, Cronbach's Alpha Standardized Items $=0,862$, dan $N$ of Items $=6$. Koefisien Cronbach's Alpha sebesar 0,862 > 0,6, hal ini menunjukkan bahwa seluruh instrument yang digunakan untuk mengukur variabel "koordinasi" adalah reliable. 
Tabel 2. Validitas variabel koordinasi

\begin{tabular}{lccc}
\hline $\begin{array}{c}\text { Indikator/item } \\
\text { instrumen }\end{array}$ & $\begin{array}{c}\text { Corrected } \\
\text { item-total } \\
\text { correlation }\end{array}$ & $\mathbf{r}_{\text {tabel }}$ & Justifikasi \\
\hline Koordinasi-1 & 0,663 & 0,23 & valid \\
Koordinasi-2 & 0,664 & 0,23 & valid \\
Koordinasi-3 & 0,670 & 0,23 & valid \\
Koordinasi-4 & 0,698 & 0,23 & valid \\
Koordinasi-5 & 0,657 & 0,23 & valid \\
Koordinasi-6 & 0,306 & 0,23 & valid \\
Koordinasi-7 & 0,430 & 0,23 & valid \\
\hline
\end{tabular}

3. Uji validitas variabel "integrasi"

Dari hasil analisis validitas variabel integrasi dengan menggunakan program SPSS diperoleh hasil pada Tabel 3 .

Tabel 3. Validitas variabel "integrasi"

\begin{tabular}{cccc}
\hline Indikator & $\begin{array}{c}\text { Corrected } \\
\text { item-total }\end{array}$ & $\mathbf{R}_{\text {tabel }}$ & Justifikasi \\
\hline Integrasi-1 & 0,639 & 0,23 & valid \\
Integrasi-2 & 0,809 & 0,23 & valid \\
Integrasi-3 & 0,581 & 0,23 & valid \\
Integrasi-4 & 0,679 & 0,23 & valid \\
Integrasi-5 & 0,638 & 0,23 & valid \\
Integrasi-6 & 0,603 & 0,23 & valid \\
\hline
\end{tabular}

Nilai corected item - total correlation untuk semua indikator lebih besar dari 0,23, yang artinya seluruh indikator yang membangun variabel "Integrasi" adalah valid atau sesuai antara instrument dengan yang diukurnya.

\section{Uji reliabilitas variabel "integrasi"}

Analisis reliabilitas variabel integrasi dengan menggunakan program SPSS diperoleh hasil Cronbach's Alpha $=0,863$, Cronbach's Alpha Standardized Items $=0,862$, dan $N$ of Items $=6$. Koefisien Cronbach's Alpha sebesar 0,862 > 0,6, hal ini menunjukanbahwa seluruh instrument yang digunakan untuk mengukur variabel "integrasi" adalah reliable.

\section{Uji validitas variabel "sinkronisasi"}

Dari hasil analisis validitas variabel sinkronisasi dengan menggunakan program SPSS diperoleh hasil pada Tabel 4. Nilai corected item - total correlation untuk semua indikator lebih besar dari 0,23 yang artinya seluruh indikator yang membangun variabel "sinkronisasi" adalah valid atau sesuai antara instrument dengan yang diukurnya.
Tabel 4. Validitas variabel "sinkronisasi"

\begin{tabular}{cccc}
\hline Indikator & $\begin{array}{c}\text { Corrected } \\
\text { item-total }\end{array}$ & $\mathbf{R}_{\text {tabel }}$ & Justifikasi \\
\hline Sinkronisasi-1 & 0,417 & 0,23 & valid \\
Sinkronisasi-2 & 0,776 & 0,23 & valid \\
Sinkronisasi-3 & 0,677 & 0,23 & valid \\
Sinkronisasi-4 & 0,639 & 0,23 & valid \\
Sinkronisasi-5 & 0,545 & 0,23 & valid \\
Sinkronisasi-6 & 0,691 & 0,23 & valid \\
\hline
\end{tabular}

6. Uji reliabilitas variabel "sinkronisasi"

Analisis reliabilitas variabel sinkronisasi dengan menggunakan program SPSS diperoleh hasil Cronbach's Alpha $=0,875$, Cronbach's Alpha Standardized Items $=0,878$, dan $N$ of Items $=6$. Koefisien Cronbach's Alpha sebesar 0,875 >0,6, hal ini menunjukan bahwa seluruh instrumen yang digunakan untuk mengukur variabel "sinkronisasi" adalah reliable.

\section{Uji validitas variabel "senergitas"}

Dari hasil analisis validitas variabel senergitas dengan menggunakan program SPSS diperoleh hasil pada Tabel 5 .

\section{Tabel 5. Validitas variabel "sinergitas"}

\begin{tabular}{cccc}
\hline Indikator & $\begin{array}{c}\text { Corrected } \\
\text { item-total }\end{array}$ & $\mathbf{R}_{\text {tabel }}$ & Justifikasi \\
\hline sinergitas-1 & 0,654 & 0,23 & valid \\
sinergitas-2 & 0,625 & 0,23 & valid \\
sinergitas-3 & 0,769 & 0,23 & valid \\
sinergitas-4 & 0,742 & 0,23 & valid \\
sinergitas-5 & 0,695 & 0,23 & valid \\
sinergitas-6 & 0,612 & 0,23 & valid \\
\hline
\end{tabular}

Nilai corected item - total correlation untuk semua indikator lebih besar dari 0,23, yang artinya seluruh indikator yang membangun variabel "sinergitas" adalah valid atau sesuai antara instrument dengan yang diukurnya.

\section{Uji reliabilitas variabel "sinergitas"}

Analisis reliabilitas variabel sinergitas dengan menggunakan program SPSS diperoleh hasil Cronbach's Alpha $=0,875$, Cronbach's Alpha Standardized Items $=0,878$ dan $N$ of Items $=6$. Koefisien Cronbach's Alpha sebesar 0,875>0,6, hal ini menunjukan bahwa seluruh instrumen yang digunakan untuk mengukur variabel "sinkronisasi" adalah reliable. 


\section{Indeks stakeholders dalam pengelolaan DAS}

Analisis ini mendiskripsikan besaran tingkat KISS yang telah dilakukan oleh stakeholders dalam pengelolaan DAS di Indonesia. Diskripsi dijabarkan secara umum maupun parsial per masing-masing variabel KISS, yakni variabel koordinasi, integrasi, sinkronisasi dan sinergitas pada Tabel 6. Dalam penentuan kategori indeks stakeholders dibedakan menjadi tiga klasifikasi dengan batasan besaran indeks dimana besaran indeks $(25,00 \mathrm{~s} / \mathrm{d}<50,00)$ diklasifikasikan kategori kurang besaran indeks $(50,00 \mathrm{~s} / \mathrm{d}<75,00)$ diklasifikasikan kategori sedang, dan besaran indeks $(75,00 \mathrm{~s} / \mathrm{d}<100,00)$ diklasifikasikan kategori baik. Analisis dengan metode angka indeks memberikan hasil secara umum pengelolaan DAS di Indonesia termasuk dalam kriteria "sedang" dengan angka indeks 71,4. Keempat variabel pengelolaan DAS, yakni: koordinasi, integrasi, sinkronisasi dan sinergitas, semuanya termasuk dalam kriteria "sedang" , dengan kisaran angka indeks 70,05 s/d 72,69.

Secara rating dari yang terbaik dapat dinyatakan: terbaik pertama adalah variabel koordinasi, dengan angka indeks 72,69. Terbaik kedua adalah Variabel integrasi, dengan angka indeks 72,50. Terbaik ketiga adalah variabel sinkronisasi, dengan angka indeks 70,34 dan terbaik keempat adalah variabel sinergitas, dengan angka indeks 70,05.

\section{Variabel koordinasi}

Untuk variabel koordinasi masih terdapat lima indikator yang kreterianya masih "sedang", yaitu pengelolaan DAS mengacu pada RPDAST (k.2), dalam pengelolaan DAS sering melakukan pertemuan incidental dengan pihak/instansi lain (k.3), dalam pengelolaan DAS sering melakukan pertemuan terjadual dengan pihak/instansi lain (k.4), dalam perencanaan DAS masukan dari masyarakat cukup diakomodir (k.6), ini sebagai salah satu mekanisme koordinasi (Grigg, 2016), untuk saling bertemu, sehingga terhindar dari konflik antar stakeholders. Mengkomunikasikan hasil monev dengan pihak lain yang relevan.

Ada dua indikator yang sudah termasuk kriteria baik, yaitu dalam penentuan RPDAST sudah melibatkan multi pihak yang relevan (k.1) dan dalam pengelolaan DAS sering melibatkan kelompok-kelompok masyarakat yang relevan (k.5).

Tabel 6. Hasil analisis indeks

\begin{tabular}{|c|c|c|c|c|c|c|c|}
\hline Variabel & Item/indikator & $\begin{array}{l}\text { Indeks } \\
\text { item }\end{array}$ & $\begin{array}{l}\text { Katagori } \\
\text { item }\end{array}$ & $\begin{array}{c}\text { Indeks } \\
\text { variabel }\end{array}$ & $\begin{array}{l}\text { Katagori } \\
\text { variabel }\end{array}$ & $\begin{array}{c}\text { Indeks } \\
\text { stakeholders }\end{array}$ & $\begin{array}{c}\text { Katagori indeks } \\
\text { stakeholders }\end{array}$ \\
\hline \multirow[t]{7}{*}{ koordinasi } & k.1 & 75,38 & baik & 72,69 & sedang & & \\
\hline & k. 2 & 71,15 & sedang & & & & \\
\hline & k. 3 & 73,46 & sedang & & & & \\
\hline & k. 4 & 73,46 & sedang & & & & \\
\hline & k.5 & 75,77 & baik & & & & \\
\hline & k.6 & 66,92 & sedang & & & & \\
\hline & k.7 & 72,69 & sedang & & & & \\
\hline \multirow[t]{6}{*}{ integrasi } & i. 1 & 75,40 & baik & 72,50 & sedang & & \\
\hline & i. 2 & 74,60 & sedang & & & & \\
\hline & i. 3 & 71,37 & sedang & & & & \\
\hline & $\mathrm{i} .4$ & 68,65 & sedang & & & & \\
\hline & i. .5 & 70,83 & sedang & & & & \\
\hline & i. 6 & 74,15 & sedang & & & 71,40 & sedang \\
\hline \multirow[t]{6}{*}{ sinkronisasi } & sk.1 & 70,16 & sedang & 70,34 & sedang & & \\
\hline & sk.2 & 70,08 & sedang & & & & \\
\hline & sk.3 & 68,55 & sedang & & & & \\
\hline & sk.4 & 72,18 & sedang & & & & \\
\hline & sk.5 & 71,72 & sedang & & & & \\
\hline & sk.6 & 69,35 & sedang & & & & \\
\hline \multirow[t]{6}{*}{ sinergitas } & sn.1 & 69,92 & sedang & 70,05 & sedang & & \\
\hline & $\operatorname{sn} .2$ & 70,97 & sedang & & & & \\
\hline & $\operatorname{sn} .3$ & 70,56 & sedang & & & & \\
\hline & sn. 4 & 68,95 & sedang & & & & \\
\hline & $\operatorname{sn} .5$ & 68,95 & sedang & & & & \\
\hline & sn.6 & 70,97 & sedang & & & & \\
\hline
\end{tabular}




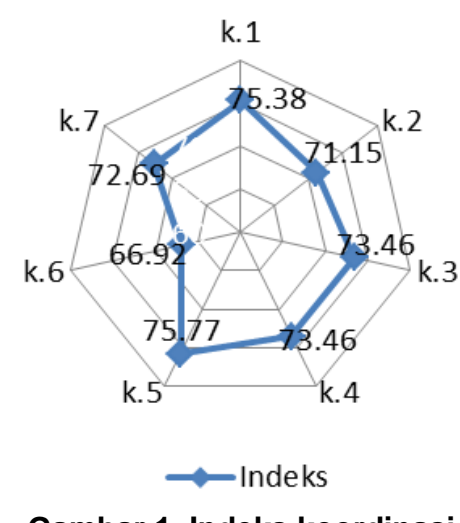

Gambar 1. Indeks koordinasi

\section{Variabel integrasi}

Untuk variabel integrasi masih terdapat lima indikator yang kreterianya masih "sedang", yaitu pengelolaan DAS sudah ada pembagian wilayah kerja dengan lembaga lain secara proporsional (i.2), dalam pengelolaan DAS sudah ada pembagian substansi kegiatan dengan lembaga lain secara pro-porsional (i.3), dalam pengelolaan DAS sudah mencerminkan pembagian beban biaya dan manfaat dengan lembaga lain secara proporsional (i.4), sehingga tercapai efisiensi biaya dan waktu (Charlton \& Tufgar, 1991), hasil monitoring evaluasi pengelolaan DAS sudah terintegrasi dengan lembaga lain yang relevan (i.5), hasil monitoring evaluasi pengelolaan DAS dapat menumbuhkan kesepakatan program dengan instansi lain (i.6).

Hanya ada satu indikator yang kriterianya "baik", yaitu: penyusunan program RPDAST menyatukan program stakeholders secara proporsional (i.1).

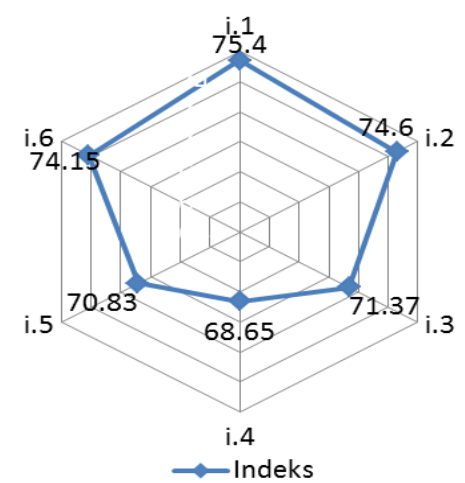

Gambar 2. Indeks integrasi

\section{Variabel sinkronisasi}

Untuk variabel sinkronisasi semua indikator termasuk kriteria "sedang" sehingga semua indikator harus diupayakan perbaikan. Keenam indikator tersebut adalah (1) Penyusunan RPDAST sudah menyamakan waktu pelaksanaan program. (2) Dokumen RPDAST sudah berdasarkan data dari multi pihak. (3) Pelaksanaan kegiatan pengellaan DAS sudah ada kesesuaian waktu dengan multi pihak. (4) Dalam pengelolaan DAS sudah memiliki target sektoral yang jelas. (5) Dalam pengelolaan DAS sudah memiliki target lintas sektoral yang jelas. (6) Kegiatan monitoring evaluasi DAS sudah sesuai dengan masing-masing program instans.

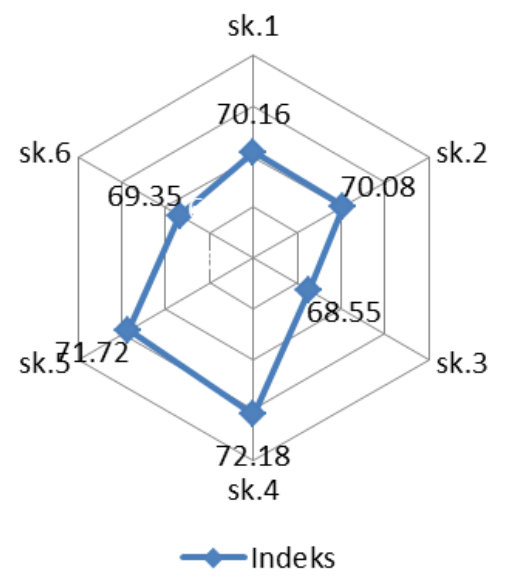

Gambar 3. Indeks sinkronisasi

\section{Variabel sinergitas}

Untuk variabel sinergitas, sebagai variabel yang menunjukkan para pihak saling mengisi satu dengan yang lain, bila beda pendapat atau mengalami konflik, diselesaikan dengan cara win win solusion, secara sosial, tidak mencari menang atau kalah (Mirchi et al., 2010). Semua indikator masuk kriteria "sedang" sehingga semua indikator harus diupayakan perbaikan. Keenam indikator tersebut adalah (1) Penyusunan RPDAST sudah mencerminkan kesepakatan bersama antar stakeholder. (2) Kegiatan pengelolaan DAS sudah berorientasi pada tujuan yang adaptif terhadap perubahan kondisi yang dinamis dan sesuai dengan karakteristik wilayah DAS. (3) Bentuk dan jenis kegiatan pengelolaan DAS sudah adaptif terhadap perubahan kondisi yang dinamis dan sesuai dengan karakteristik wilayah DAS. (4) Dalam pengelolaan DAS disediakan jenis kegiatan yang dapat mengakomodir masukan dan keterlibatan masyarakat. (5) Pelaksanaan kegiatan pengelolaan DAS sudah mencerminkan kerja sama yang saling melengkapi antar multi pihak di wilayah DAS (hulu, tengah dan hilir). (6) Hasil monitoring evaluasi pengelolaan DAS dari masing-masing puhak dapat saling memberikan sumbangan dalam pengelolaan DAS terpadu. 


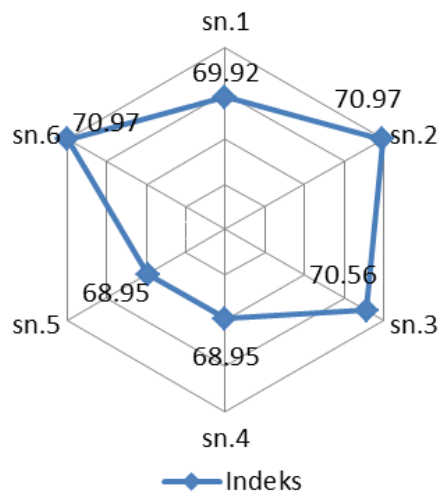

Gambar 4. Indeks sinergitas

\section{Kesimpulan}

Tingkat ukuran KISS yang telah dilakukan oleh stakeholders dalam pengelolaan DAS di Indonesia, pada umumnya masih termasuk dalam katagori sedang (indeks: 74,31), yakni variabel koordinasi, integrasi, sinkronisasi dan sinergitas masuk dalam kriteria sedang.

Unsur koordinasi masih terdapat lima indikator yang memiliki kriteria sedang, dan harus ditingkatkan pelaksanaannya, kelimanya adalah: menjadikan RPDAST sebagai acuan utama dalam pengelolaan DAS, melakukan pertemuanpertemuan incidental dengan pihak/instansi lain, melakukan pertemuan yang terjadual dengan pihak/instansi lain, mengakomodir masukanmasukan dari masyarakat yang relevan, mengkomunikasikan hasil monitoring evaluasi dengan pihak lain yang relevan.

Unsur integrasi memiliki lima indikator yang kreterianya sedang, dan harus ditingkatkan, kelimanya adalah melakukan pembagian wilayah kerja yang proporsional dengan pihak lain, melakukan pembagian substansi kegiatan dengan lembaga lain secara proporsional, kegiatan pengelolaan DAS harus mencerminkan pembagian beban biaya dan manfaat dengan lembaga lain secara proporsional, hasil monitoring evaluasi DAS harus terintegrasi dengan lembaga lain yang relevan (i.5) hasil monitoring evaluasi DAS dapat menumbuhkan kesepakatan program dengan instansi lain.

Semua indikator sinkronisasi memiliki kriteria sedang dan keenamnya harus diupayakan perbaikan. Keenam indikator tersebut: penyusunan RPDAST sudah menyamakan waktu pelaksanaan program, dokumen RPDAST harus berdasarkan data dari multi pihak, adanya kesesuaian waktu dengan multi pihak, menentukan target sektoral yang jelas, menentukan target lintas sektoral yang jelas, kesesuaian program kegiatan monitoring evaluasi dengan masing-masing program instansi

Variabel sinergitas memiliki enam indikator yang semuamya termasuk dalam kriteria "sedang" dan harus diupayakan perbaikan, keenam indikator tersebut meliputi: penyusunan RPDAST harus mencerminkan kesepakatan bersama antar multi pihak, kegiatan pengelolaan DAS harus adaptif terhadap perubahan kondisi yang dinamis dan sesuai dengan karakteristik wilayan DAS, bentuk dan jenis kegiatan pengelolaan DAS harus adaptif terhadap perubahan kondisi yang dinamis dan sesuai dengan karakteristik wilayan DAS, dalam kegiatan pengelolaan harus dapat mengakomodir masukan dan keterlibatan masyarakat, kegiatan pengelolaan DAS harus mencerminkan kerja sama yang saling melengkapi antar multi pihak di wilayah DAS (hulu, tengah dan hilir), hasil program monitoring evaluasi DAS dari masing masing pihak harus dapat saling memberikan sumbangan, karena hal tersebut merupakan elemen kunci dalam perencanaan dan pelaksanaan (Gregersen et al., 2007), dalam pengelolaan DAS terpadu.

\section{Saran}

Tingkatkan saat pelaksanaan fisik mengacu pada dokumen perencana yang telah di sepakati bersama, berikut peningkatan intensitas pertemuan antar stakeholders. Perlu peningkatan keterlibatan masyarakat dalam pembuatan dokumen perencanaan dan tingkatkan koordinasi hasil monitoring dan evaluasi kepada stakeholders. Tingkatkan Pelaksanaan kegiatan sesuai dengan pembagian wilayah dan substansi, sehingga capaian integrasi lebih baik. Proposinalitas dalam pembebanan biaya maupun nilai manfaat bagi semua stakeholders perlu ditingkatkan. Tingkatkan sinkronisasi perencanaan dokumen baik waktu maupun data yang digunakan, tugas dan waktu pelaksanaan oleh stakeholders, berikut hasil monitoring dan evaluasi. Adanya perbedaan kegiatan yang harus dilakukan oleh stakeholders untuk mencapai sinergitas perlu ditingkatkan.

\section{Ucapan Terima Kasih}

Ucapan terima kasih, kami sampaikan kepada yang terhormat Menteri Pekerjaan Umum dan Perumahan Rakyat, Menteri Lingkungan Hidup dan Kehutanan Republik Indonesia, dan Rektor Universitas Diponegoro Semarang atas kesempatan yang telah diberikan kepada kami, serta seluruh peserta Focus Group Discussion Hari Air Dunia XV111, "Kemitraan dalam Upaya Pelestarian dan Perlindungan Sumber Daya Air 
yang telah berkenan mengisi kuesioner, wawancara/diskusi terkait penelitian yang kami lakukan.

\section{Daftar Pustaka}

Bewket, W. (2003). Towards integrated watershed management in highland Ethiopia: the Chemoga watershed case study. Tropical Resource Management Papers 44 [PhD dissertation], Netherland: The Wageningen University and Research Centre.

Borisova, T., Racevskis, L., \& Kipp, J. (2012). Stakeholder analysis of a collaborative watershed management process: A Florida case study. JAWRA Journal of the American Water Resources Association, 48(2), 277-296.

Chanya, A., Prachaak, B., \& Ngang, T. K. (2014). Conflict Management on use of watershed resources. Procedia-Social and Behavioral Sciences, 136, 481-485.

Charlton, D. L., \& Tufgar, R. (1991). Integrated watershed management approach for small southern Ontario rural/urban watersheds. Canadian Water Resources Journal, 16(4), 421-432.

Donaldson, T., \& Preston, L. E. (1995). The stakeholder theory of the corporation: Concepts, evidence, and implications. Academy of management Review, 20(1), 65-91.

Erdogan, R. (2013). Stakeholder involvement in sustainable watershed management. In Murat Ozyavuz (Ed), Advances in Landscape Architecture (pp 131-168). Rijeka: InTech.

Ferdinand, A. (2006). Metode penelitian manajemen, pedoman penelitian untuk penulisan skripsi, tesis dan disertasi ilmu manajemen. Semarang: Badan Penerbit Universitas Diponegoro.

Freeman, R. E. (1984). Strategic management : A stakeholder approach. Boston: Blackwell Publishing.

Freeman, R. E., \& McVea, J. (2001). A stakeholder approach to strategic management. The Blackwell handbook of strategic management, 183-201.
Ghozali, I. 2011. Aplikasi Analisis Multivariate dengan Program IBM SPSS 19 Edisi 5. Semarang: BP Universitas Diponegoro

Freeman, R. E. (2004). The Stakeholder Approach Revisited.https://www.researchgate.net/publicatio $n / 228946075$

Gregersen, H.M. P.F. Ffolliott and K.N. Brooks (2007). Integrated Watershed Management. CABI Head Office Nosworthy Way Wallingford Oxfordshire OX10 8 DE UK b site: Wewww.cabi.org

Grigg, N. S. (1998). Coordination: the key to integrated water management. Water Resources Update, 111, 23-29.

Grigg, N. S. (2016). Integrated Water Resource Management, DOI 10.1057/978-1-137-57615-6_1

Jones, C., Palmer, R. M., Motkaluk, S., \& Walters, M. (2002). Watershed health monitoring: emerging technologies. CRC Press.

Mirchi, A., Watkins Jr, D., \& Madani, K. (2010). Modeling for watershed planning, management, and decision making. In Jeremy C. Voughn (Ed), Watersheds: Management, restoration and environmental impact. (pp. 1-25). New York: Nova Science Publishers.

Mutekanga, F. P., Kessler, A., Leber, K., \& Visser, S. (2013). The use of stakeholder analysis in integrated watershed management: Experiences from the Ngenge Watershed, Uganda. Mountain Research and Development, 33(2), 122-131.

Republik Indonesia. (2012). Peraturan Pemerintah No 37 Tahun 2012 tentang Pengelolaan Daerah Aliran Sungai. Jakarta: Sekretariat Negara.

Sciarelli, M., \& Tani, M. (2013). Network approach and stakeholder management. Bussiness System Review, 2(2), 175-190.

Winnegge, R. (2005). Participatory Approach in Integrated Watershed Management. Paper presented at Proceedings of Topics of Integrated Watershed Management, 3, 187-202. 